\title{
Evaluation of anti-inflammatory, cytotoxic, anti-H. pylori, antioxidant activities, and phytochemical compositions of Shirakiopsis indica (Willd.) Esser
}

\author{
Khwanchanok Mokmued $^{\mathrm{a}}$, Bhanuz Dechayont ${ }^{\mathrm{b}}$, Pathompong Phuaklee ${ }^{\mathrm{b}}$, Chantubpapa Liplung ${ }^{\mathrm{b}}$, \\ Harit Muangpoolsawad $^{\mathrm{b}}$, Nitra Nuengchamnong ${ }^{\mathrm{c}}$, Nuntika Prommee ${ }^{\mathrm{a}, *}$ \\ a Division of Applied Thai Traditional Medicine, Faculty of Public Health, Naresuan University, \\ Phitsanulok 65000 Thailand \\ b Department of Applied Thai Traditional Medicine, Faculty of Medicine, Thammasat University, Pathum \\ Thani 12120 Thailand \\ c Science Laboratory Centre, Faculty of Science, Naresuan University, Phitsanulok 65000 Thailand
}

*Corresponding author, e-mail: nuntikap@nu.ac.th

Received 10 Jan 2021

Accepted 4 Jun 2021

\begin{abstract}
Shirakiopsis indica (Willd.) Esser (Sa-Mor-Ta-Lay, in Thai), a herbal plant belonging to the family Euphorbiaceae, has traditionally been used to treat gastrointestinal symptoms. The objectives of this study were to investigate the bioactivities (cytotoxic, antioxidant, anti-inflammatory, and anti-Helicobacter pylori) of $S$. indica extracts that influence the treatment of gastric inflammation. The chemical constituents of the extracts were also analyzed by performing LC-ESI-QTOF-MS/MS; and they are tentatively identified as Sapintoxin A, Sapintoxin B, Sapintoxin C, Saipinin, and a few other phorbol esters. We found that the ethanolic extract of $S$. indica exhibited the highest cytotoxicity against the Kato III gastric cancer cell line and the highest inhibition of nitric oxide production with the $\mathrm{IC}_{50}$ values of $3.21 \pm 0.77$ and $12.99 \pm 2.42 \mu \mathrm{g} / \mathrm{ml}$, respectively. The water extract of $S$. indica exhibited higher anti$H$. pylori activity than that of the ethanolic extract, and exhibited strong antioxidant activity on DPPH and ABTS ${ }^{+}$assay with the $\mathrm{IC}_{50}$ values of $8.169 \pm 0.65$ and $20.03 \pm 1.33 \mu \mathrm{g} / \mathrm{ml}$, respectively. Our results give new science-based evidence that $S$. indica fruit extract has a potential for treatment of gastritis. Pharmacological activities and toxicity in animal models should be further investigated.
\end{abstract}

KEYWORDS: Shirakiopsis indica, anti-inflammatory, cytotoxic, antioxidant, anti-H. pylori

\section{INTRODUCTION}

Gastritis is the inflammation of gastric mucosa. The pathological base of gastritis is dystrophy, inflammation, and unregeneration of gastric mucosa causing atrophy as the outcome of these symptoms [1]. The stomach has mechanisms to protect against hydrochloric acid and toxic agents. For example, gastric mucosa can control the acid and pepsin enzyme production, and the thickness of the gastric mucous coating can prevent acid toxicity in the stomach [2]. The inflammation of gastric mucosa or gastritis is a disorder of the stomach. There are two main causes of gastritis: Helicobacter pylori (H. pylori) infection and non-steroidal antiinflammatory drugs (NSAIDs). H. pylori is a grade I carcinogenic bacterium that causes gastric cancer in humans [3], the most common non-erosive gastritis classified by International Agency for Research on Cancer (IARC), World Health Organization (WHO). In response to the $H$. pylori infection, the human body mechanism reacts to the inflammation site and generates reactive oxygen species (ROS) and reactive nitrogen species (RNS), i.e., nitric oxide and superoxide [4]. Nowadays, the treatment of gastritis varies according to the cause, but the primary problem has not been solved. Various herbs have been used in Thai traditional medicine to treat gastritis and peptic ulcers $[5,6]$. The most common herb used for treating gastrointestinal symptoms is the fruit of Shirakiopsis indica (Sa-Mor-Ta-Lay in Thai). However, bioactivities of this herb have never been reported. The objectives of this study were to investigate the bioactivities of $S$. indica that influence the treatment of gastric inflammation, including cytotoxic activity against Kato III gastric 
cancer cell line using the Sulforhodamine B (SRB) assay, antioxidant activity by DPPH and $\mathrm{ABTS}^{++}$ assay, proinflammatory cytokines, i.e., nitric oxide (NO) by Griess assay, tumor necrosis-alpha (TNFalpha), interleukin-6 (IL-6) using an ELISA kit assay, and anti-H. pylori using disc diffusion and minimal inhibitory concentration (MIC) assay. In addition, the chemical constituents of $S$. indica fruits were analyzed by performing LC-ESI-QTOF-MS/MS.

\section{MATERIALS AND METHODS}

\section{Sample collection}

Dried fruits of Shirakiopsis indica (Willd.) Esser $(1000 \mathrm{~g})$ were obtained from a local herbal medicine shop "Charoensuk Osod" in Nakorn Pathom, Thailand. Species identification, Verification Number 05698, was verified by the Herbarium in the Department of Biology, Faculty of Science, Naresuan University, Thailand, and this study was approved by the Biosafety Committee of University of Thammasat, Thailand under Biosafety Level 2 (BSL II, Number 011/2019).

\section{Sample extraction and preparation}

\section{Water extraction}

Dried S. indica fruits (92.49 g) were boiled in 500 $\mathrm{ml}$ of distilled water for $15 \mathrm{~min}$, and the aqueous extract was filtered through a Whatman filter paper No. 1. Then, the filtrate was freeze dried using lyophilizer (Lyophilization systems Inc, USA).

\section{Ethanolic extraction}

Dried S. indica fruits $(208.09 \mathrm{~g})$ were crushed with in a mortar and macerated with 11 of $95 \%$ ethanol for 3 days. The extract was filtered through Whatman filter paper No. 1 and re-macerated twice. Then, the combined extract was dried using a rotary evaporator (Buchi, Switzerland).

\section{Cell culture}

\section{Human and murine macrophage cell lines}

The Kato III gastric cancer cell line was obtained from the Riken Cell Bank (Tsukuba, Japan; catalog no. RCB2088). It was cultured in RPMI 1640 medium supplemented with $10 \%$ heated fetal bovine serum, $50 \mathrm{IU} / \mathrm{ml}$ of penicillin, and $50 \mu \mathrm{g} / \mathrm{ml}$ of streptomycin. For the anti-inflammatory activity, the murine macrophage RAW 264.7 cells (ATCC ${ }^{\circledR}$ TIB-71TM VA, USA) were cultured in DMEM (Dulbecco's Modified Eagle Medium) supplemented with
$10 \%$ heated fetal bovine serum, $50 \mathrm{IU} / \mathrm{ml}$ of penicillin, and $50 \mu \mathrm{g} / \mathrm{ml}$ of streptomycin. The cells cultured were maintained at $37^{\circ} \mathrm{C}$ in $5 \% \mathrm{CO}_{2}$ incubator (Shel lab, USA) at 95\% humidity.

\section{Bacterial strains and culture conditions}

H. pylori (ATCC® 43504, USA) was obtained from the American Type Culture Collection. It was cultured on Columbia agar supplemented with $5 \%$ sheep's blood (RPD, Thailand) and incubated at $37^{\circ} \mathrm{C}$ under microaerobic conditions $\left(\mathrm{N}_{2}, 85 \% ; \mathrm{O}_{2}\right.$, $\left.5 \% ; \mathrm{CO}_{2}, 10 \%\right)$ using a gas generating kit. The bacteria were sub-cultured every three days in an anaerobic jar.

\section{Antioxidant activities}

\section{DPPH radical scavenging assay}

DPPH was measured by the method of Yamasaki et al [7] with a slight modification. DPPH solution (Fluka, USA) in absolute ethanol was freshly prepared and kept in a dark bottle protected from light. A $100 \mu \mathrm{l}$ each of the water and ethanolic extracts and butylated hydroxytoluene (BHT) solutions of various concentrations $(1,10,50$, and $100 \mu \mathrm{g} / \mathrm{ml}$ ) were placed in each well of a 96 well microplate. After that, a $100 \mu l$ of the DPPH solution was added to each well, and the plate was incubated in the dark at room temperature for 30 min. The radical scavenging activity was expressed as the number of antioxidants necessary to decrease the initial DPPH absorbance by $50 \%\left(\mathrm{IC}_{50}\right)$. The antioxidant activity was calculated by its ability to inhibit the DPPH radical formation according to Eq. (1):

$$
\% \text { Inhibition }=\frac{\left(\mathrm{Abs}_{\text {Control }}-\mathrm{Abs}_{\text {Sample }}\right)}{\mathrm{Abs}_{\text {Control }}} \times 100
$$

where $\mathrm{Abs}_{\text {Control }}=$ absorbance of absolute ethanol; $\mathrm{Abs}_{\text {Sample }}=$ absorbance of fruit extract.

\section{ABTS $^{+}$radical scavenging assay}

The herbal extracts of $1,10,50$, and $100 \mu \mathrm{g} / \mathrm{ml}$ concentrations were diluted. Then, $\mathrm{ABTS}^{+}{ }^{+}$solution was prepared by diluting $7 \mathrm{mM} \mathrm{ABTS}{ }^{+}$stock solution in distilled water with $2.45 \mathrm{mM}$ potassium persulfate and then mixed at room temperature for $12-16 \mathrm{~h}$. The solution was diluted with distilled water to obtain an absorbance at $734 \mathrm{~nm}$ in the range of $0.68-0.72$. A $10 \mu \mathrm{l}$ aliquots of diluted ABTS ${ }^{+}$ solution and $90 \mu \mathrm{l}$ of one of the $S$. indica extracts or standard Trolox were added into each well of the 96 well microplate, and mixed well. Then, the plate 
was incubated for $6 \mathrm{~min}$, and the absorbance (Abs) was measured at $734 \mathrm{~nm}$ by a microplate reader [8]. The antioxidant (radical scavenging) activity was calculated as percent inhibition of $\mathrm{ABTS}^{++}$radical formation according to Eq. (2):

$$
\% \text { Inhibition }=\frac{\left(\mathrm{Abs}_{\text {Control }}-\mathrm{Abs}_{\text {Sample }}\right)}{\mathrm{Abs}_{\text {Control }}} \times 100
$$

where $\mathrm{Abs}_{\text {Control }}=$ absorbance of absolute ethanol; $\mathrm{Abs}_{\text {Sample }}=$ absorbance of fruit extract. The radical scavenging activity was expressed as the number of antioxidants $(\mu \mathrm{g} / \mathrm{ml})$ necessary to decrease the initial $\mathrm{ABTS}^{++}$absorbance by $50 \%\left(\mathrm{IC}_{50}\right.$ ).

\section{Anti-inflammatory activity on nitric oxide production and cytotoxicity}

\section{Anti-inflamatory activity on nitric oxide production}

The anti-inflammatory activity of $S$. indica on nitric oxide production in murine macrophage RAW 264.7 cell line was determined by Griess assay [9-11]. The RAW 264.7 cells were diluted with the medium to obtain an optical density of $1 \times 10^{5}$. A 96 well microplate was seeded with $100 \mu \mathrm{l} /$ well of the cell suspension and incubated at $37^{\circ} \mathrm{C}$ in $5 \% \mathrm{CO}_{2}$ incubator (Shel lab, USA) at 95\% humidity for $24 \mathrm{~h}$. Next, $100 \mu \mathrm{l}$ of fresh medium containing $10 \mathrm{ng} / \mathrm{ml}$ of lipopolysaccharide (LPS) (Sigma-Aldrich, USA) and various concentrations of test samples $(1,10$, $30,50$, and $100 \mu \mathrm{g} / \mathrm{ml})$ in DMSO $(100 \mu \mathrm{l} /$ well $)$ were added to the wells and incubated for $24 \mathrm{~h}$. The last step, after incubation for $24 \mathrm{~h}$, nitric oxide production was determined with Griess reagent. Aliquots of $100 \mu \mathrm{l}$ of the supernatant were transferred into a new 96 well microplate and mixed with $100 \mu l$ of Griess reagent. The absorbance (Abs) of the supernatants was measured with the microplate reader (Bio Tek, USA) at $540 \mathrm{~nm}$. Inhibition was expressed as a percentage relative to the control samples, and dose-response curves were generated with Prism software (version 12) to determine the $\mathrm{IC}_{50}$ of the extracts. All the ethanol and water extract concentrations used in this anti-inflammatory activity on nitric oxide production were later tested for potential cytotoxicity in the MTT assay according to Eq. (3):

$$
\% \text { Inhibition }=\frac{\left(\mathrm{Abs}_{\text {cont diff }}-\mathrm{Abs}_{\text {sample diff }}\right)}{A b s_{\text {cont diff }}} \times 100
$$

where $\mathrm{Abs}_{\text {cont diff }}=\mathrm{Abs}_{\text {control(+LPS) }}-\mathrm{Abs}_{\text {control(-LPS) }}$; $\mathrm{Abs}_{\text {sample diff }}=\mathrm{Abs}_{\text {sample }(+\mathrm{LPS})}-\mathrm{Abs}_{\text {sample (-LPS) }}$.

\section{MTT assay for potential cytotoxicity}

An MTT assay [10] was used to assess cytotoxicity of the $S$. indica extracts on RAW 264.7 cell line. The cells $\left(1 \times 10^{5}\right.$ cells/well $)$ were incubated in 96 well microplates with various extract concentrations $(1,10,30,50$, and $100 \mu \mathrm{g} / \mathrm{ml})$ for $48 \mathrm{~h}$. Then, the thiazolyl blue tetrazolium bromide (MTT) solution (Sigma-Aldrich, USA) was added to these wells and incubated for another $4 \mathrm{~h}$. Next, the medium was removed, and isopropanol buffer (RCI Labscan, Thailand) with $0.04 \mathrm{M} \mathrm{HCl}$ was added to dissolve the formazan produced in the incubated cells. The absorbance of the formazan solution was measured with a microplate reader (Bio Tek, USA) at $570 \mathrm{~nm}$. A dose-response curve was obtained by plotting the $\%$ inhibition values versus the extract concentrations. The extracts were considered nontoxic when cell survival was more than $70 \%$. Cell survival was followed by determining $\%$ toxicity according to Eq. (4):

$$
\text { (\%) Toxicity }=\frac{\left(\mathrm{Abs}_{\text {control }}-\mathrm{Abs}_{\text {extract }}\right)}{\mathrm{Abs}_{\text {control }}} \times 100
$$

where $\mathrm{Abs}_{\text {control }}=$ absorbance of absolute ethanol; $\mathrm{Abs}_{\text {sample }}=$ absorbance of fruit extract.

\section{The inhibition of TNF- $\alpha$ and IL- 6 production}

The murine macrophage cell line (RAW 264.7 cell line) was incubated for $24 \mathrm{~h}$ with $5 \mathrm{ng} / \mathrm{ml}$ of LPS and $S$. indica extract. After $24 \mathrm{~h}$, the proinflammatory cytokines, i.e., TNF- $\alpha$ and IL- 6 productions, in each of the supernatants were determined by ELISA kit (ImmunoTools Co, Bangkok, Thailand) following the manufacturer's instructions. The contents of the 96 well microplate were determined with a microplate reader (Bio Tek, USA) at $420 \mathrm{~nm}[9,11]$.

\section{Anti-Helicobacter pylori \\ Disc diffusion method}

H. pylori was incubated at $37^{\circ} \mathrm{C}$ under microaerobic conditions for 3 days, and then adjusted to 0.5 McFarland standard equivalents. Filter paper discs (6 $\mathrm{mm}$ in diameter) were impregnated with the extract at the concentration of $1 \mathrm{mg} /$ disc. The air-dried discs were placed onto the Columbia 5\% sheep blood agar. Clarithromycin $1 \mathrm{mg} / \mathrm{ml}$ was used as a positive control. The plates were incubated as previously described for 3 days. The zone of inhibition was calculated by measuring the diameter of the inhibition zone 3 times, and the mean value was taken $[6,12]$. 


\section{Agar dilution method}

The MIC values $[13,14]$ of the $S$. indica extracts were determined using the agar dilution method and following the Clinical and Laboratory Standards Institute guidelines. Each extract was serially diluted 2 -fold in Columbia agar containing 5\% sheep's blood, and then transferred into Petri dishes (Biomed, Thailand). The final concentrations of the extracts in the culture medium ranged from 31.25 to $2000 \mu \mathrm{g} / \mathrm{ml}$. A colony of $H$. pylori ATCC 43504 was incubated in advance for $72 \mathrm{~h}$. Thereafter, the $H$. pylori colonies were harvested and suspended in brain heart infusion. These bacterial suspensions were adjusted to 2.0 McFarland standard equivalents, transferred to multiple spots on each plate $(3 \mu$ l per spot), and incubated at $37^{\circ} \mathrm{C}$ for $72 \mathrm{~h}$ under microaerobic conditions. The MIC was defined as the lowest concentration of extract visibly able to inhibit the growth of $H$. pylori after an overnight incubation. In this experiment, the DMSO (RCI Labscan, Thailand) was used to dissolve the extract. All tests were conducted in triplicate.

\section{Sulforhodamine B (SRB) assay}

The gastric Kato III cancer cell line was seeded at a density of $5 \times 10^{4}$ cells in 96 well microplates and incubated overnight before being treated for $72 \mathrm{~h}$ with various concentrations $(1,10,50$, and $100 \mu \mathrm{g} / \mathrm{ml}$ ) of the water and ethanolic extracts. Wells were then drained of liquid, and the cells were dried in an incubator for $72 \mathrm{~h}$. The well plates were incubated at $37{ }^{\circ} \mathrm{C}$ in $5 \% \mathrm{CO}_{2}$ at $95 \%$ humidity. The cytotoxicity was analyzed after 7 days of treatment. The incubation was terminated by the addition of $100 \mathrm{ml}$ per well of cold $40 \%$ (w/v) trichloroacetic acid (TCA) (Merck, Germany) left in the individual wells for $1 \mathrm{~h}$ at $4{ }^{\circ} \mathrm{C}$. The plates were rinsed 5 times with water and dried. After that, $50 \mathrm{ml}$ of $0.4 \% \mathrm{w} / \mathrm{v}$ SRB solution (Sigma-Aldrich, USA) in 1\% acetic acid (Merck, Germany) was added to each well, and the plates were further incubated for $30 \mathrm{~min}$ at room temperature. SRB binds to the protein components of living cells previously exposed to TCA. After the SRB staining, the remaining (unabsorbed) dye was removed by washing 5 times with $1 \%$ acetic acid. The plate was dried, and the dried SRB residue was dissolved in $100 \mu \mathrm{l}$ per well of $10 \mathrm{mM}$ Tris base (Sigma-Aldrich, USA). The absorbance was read at $492 \mathrm{~nm}$. A fitted dose-response curve was derived using linear regression to calculate the concentration of extract that killed $50 \%$ of the cells $\left(\mathrm{IC}_{50}\right)[15,16]$. The percentage of inhibition was calculated as follows (Eq. (5)):

$$
\% \operatorname{Inb}=\frac{\left(\mathrm{Abs}_{\text {control }}-\mathrm{Abs}_{\text {sample }}\right)}{\mathrm{Abs}_{\text {control }}} \times 100
$$

where $\mathrm{Abs}_{\text {control }}=$ absorbance of $2 \%$ of DMSO; $\mathrm{Abs}_{\text {sample }}=$ absorbance of fruit extract.

\section{LC-ESI-QTOF-MS/MS analysis}

An analysis of $S$. indicum extract was performed on an Agilent 1260 Infinity Series HPLC system (Agilent Technologies, Waldbronn, Germany) coupled with an Agilent 6540 Q-TOF-MS spectrometer (Agilent Technologies, Singapore) equipped with an electrospray ionization (ESI) interface. Chromatographic separation was on a Luna C18 (2) (150 $\mathrm{mm} \times 4.6 \mathrm{~mm}$ i.d., $5 \mu \mathrm{m}$ column (Phenomenax, Torrance, CA, USA). A $20 \mu$ l of sample solution $(20 \mathrm{mg} / \mathrm{ml})$ was injected into the LC system. The mobile phase consisted of (A) $0.1 \% \mathrm{v} / \mathrm{v}$ formic acid in water and (B) $0.1 \% \mathrm{v} / \mathrm{v}$ formic acid in acetonitrile. The elution was a linear gradient ranging from 5\% A to 95\% B lasting $30 \mathrm{~min}$ and holding at $95 \% \mathrm{~B}$ for $10 \mathrm{~min}$ before re-equilibration back to the initial condition lasting $5 \mathrm{~min}$. The flow rate was set at $0.5 \mathrm{ml} / \mathrm{min}$, and the temperature was controlled at $40^{\circ} \mathrm{C}$. The operating parameters for the ESI-MS detection were as follows: drying gas (gas $\mathrm{N}_{2}$ ) flow rate $(10.0 \mathrm{l} / \mathrm{min}$ ), drying gas temperature $\left(350^{\circ} \mathrm{C}\right)$, nebulizer pressure (30 psig), capillary $(3500 \mathrm{~V})$, skimmer (65 V), octapole RFV $(750 \mathrm{~V})$, and fragmentor voltage $(100 \mathrm{~V})$ in positive mode. The mass range was set at $\mathrm{m} / \mathrm{z} 100-1000$ Da with a $250 \mathrm{~ms} / \mathrm{spectrum}$. For fragmentation, the non-targeted MS/MS mode was set with collision energies at 10,20 , and $40 \mathrm{~V}$. All the acquisition and the analysis of data were controlled by Agilent LC-MS-QTOF MassHunter DataAcquisition Software version B.05.01 and Agilent MassHunter Qualitative Analysis Software B 06.0 (Agilent Technologies, USA), respectively. An analysis of each sample was performed in both positive and negative ionization mode [17].

\section{Statistical analysis}

The results are presented as mean \pm standard error of means (SEM) of three independent experiments. For each experiment, samples at each concentration were tested in triplicate. The \% inhibition was calculated using Microsoft Excel program. The $\mathrm{IC}_{50}$ values and statistical significance were calculated using one-way ANOVA, followed by Dunnett's multiple comparison test using the GraphPad Prism software (San Diego, CA, USA). 
Table 1 Antioxidant activities ( $\mathrm{IC}_{50}, \mu \mathrm{g} / \mathrm{ml}$ ) of fruit extracts of $S$. indica $(n=3)$.

\begin{tabular}{lcc}
\hline Fruit extract/control & ABTS $^{+}$assay & DPPH assay \\
\hline Water extract & $20.03 \pm 1.33^{* *}$ & $8.17 \pm 0.66^{*}$ \\
Ethanolic extract & $66.47 \pm 1.28^{*}$ & $50.95 \pm 1.47^{*}$ \\
Butylated hydroxyuene (BHT) & $5.66 \pm 0.26$ & $13.36 \pm 0.18$ \\
\hline
\end{tabular}

Data were analyzed by one-way ANOVA and Dunnett's multiple comparison tests. Significant difference $(*)$ is when $p<0.05$ compared with the positive control (BHT).

Table 2 Anti- $H$. pylori and cytotoxic activities of $S$. indica fruit extracts $(n=3)$.

\begin{tabular}{lccc}
\hline $\begin{array}{l}\text { Fruit extract/ } \\
\text { standard drug }\end{array}$ & $\begin{array}{c}\text { Cytotoxic activity } \\
\text { against Kato III }\end{array}$ & \multicolumn{2}{c}{ Anti-H. pylori ATCC 43504 } \\
\cline { 3 - 4 } & $\left(\mathrm{IC}_{50}, \mu \mathrm{g} / \mathrm{ml}\right)$ & $\begin{array}{c}\mathrm{DDA}^{\dagger} \\
(\mathrm{mm})\end{array}$ & $\begin{array}{c}\mathrm{MIC} \\
(\mu \mathrm{g} / \mathrm{ml})\end{array}$ \\
\hline Water extract & $21.76 \pm 1.58$ & $17.0 \pm 0.0$ & 2000 \\
Ethanolic extract & $3.21 \pm 0.77$ & $10.0 \pm 0.0$ & 1000 \\
Curcuminoid & $7.29 \pm 1.90$ & $\mathrm{NT}$ & $\mathrm{NT}$ \\
Clarithromycin & $\mathrm{NT}$ & $60.0 \pm 0.0$ & 0.5 \\
\hline
\end{tabular}

${ }^{\dagger} \mathrm{DDa}=$ disc diffusion assay; NT $=$ not tested.

\section{RESULTS AND DISCUSSION}

The extraction yields of the dried $S$. indica fruits extracted by water and ethanol were $3.77 \%$ and $1.28 \%$, respectively. The water extract exhibited higher antioxidant activity than the ethanolic extract with the $\mathrm{IC}_{50}$ values in $\mu \mathrm{g} / \mathrm{ml}$ of $20.03 \pm 1.33$ for ABTS assay and $8.169 \pm 0.66$ for DPPH assay (Table 1), while the ethanolic extract gave higher $\mathrm{IC}_{50}$ values by both assays. When compared with the positive control (BHT), the water extract exhibited 1.6-fold higher antioxidant activity by DPPH assay.

LPS is a composition of bacterial cell wall and functions as a stimulator for releasing proinflammatory cytokines. Therefore, nitric oxide indicates the capability in reducing inflammation of the extract. The determination of cell nitric oxide and toxicity were operated concurrently to ensure that the extracts did not reduce nitric oxide because the cells were dead and unable to produce nitric oxide [10]. The inhibition of nitric oxide production using Griess reaction assay was employed to determine the inhibitory activity, and the results showed that the ethanolic extract successfully reduced inflammation by inhibiting nitric oxideproduction at an $\mathrm{IC}_{50}$ of $12.99 \pm 2.42 \mu \mathrm{g} / \mathrm{ml}$ (Table 3 ). The ethanolic extract of $S$. indica exhibited inhibitory activity on nitric oxide production 7.7-fold higher than the standard drug (acetaminophen). It was previously reported that high levels of nitric oxide in patients having the $H$. pylori-infected gastric mucosa might contribute to the development of gastric cancer [18]. Besides, the ethanolic extract of $S$. indica did not show significant levels of inhibitory activity on nitric oxide production compared with the prednisolone $(p>0.05)$. There was the correlation between high levels of nitric oxide and interleukin-6 production in $H$. pylori-infection gastritis [19]. On the other hand, the water and ethanolic extracts did not show the correlation between the inhibitory activity on nitric oxide, TNF- $\alpha$, and IL- 6 productions. The previous investigation by Bhanuz et al [6] revealed that the ethanolic extract of the Amomum Krevanh fruit showed higher anti-inflammatory activities than the water extract in both nitric oxide and interleukin- 6 pathways. Additionally, the antiH. pylori and antioxidant activities of the ethanolic extract were also higher than the water extract. The results of our study, from the inhibitory activity on nitric oxide production and cytotoxic activity against gastric cancer cell line, supported our goals of treatment of $H$. pylori infection or gastritis and reducing the risk of gastric cancer [20]. Both the water and the ethanolic extracts exhibited potent activity against $H$. pylori with an inhibition zone perimeter of 17.00 and $10.00 \mathrm{~mm}$, respectively (Table 2). From the minimal inhibitory concentration (MIC) test, the ethanolic extract showed higher anti-H. pylori activity than the water extract, but the MIC values of both extracts against $H$. pylori were less than the standard drug (clarithromycin).

In the cytotoxicity assay, the ethanolic extract exhibited potent cytotoxic activity against the gastric cancer cell line with 2.27-fold higher than the curcuminoid drug (Table 2).

Five phorbol ester compounds found in the water extract are shown in Table 4. The characteristic loss of 151 Da from in-source fragmentation occurred at the interface of electrospray ionization (ESI) source for two of the five compounds. The two main compounds were found at $m / z[\mathrm{M}+\mathrm{H}]^{+}$ values of $540.26\left(t_{R} 24.1 \mathrm{~min}\right)$ and 524.26 with the other three at $t_{R} 26.9,27.8$, and $28.1 \mathrm{~min}$, and the $\mathrm{m} / \mathrm{z} 508.26[\mathrm{M}+\mathrm{H}]^{+}\left(t_{R} 32.5 \mathrm{~min}\right)$ resulted from the cleavage of methylaminobenzoate group. The structures of these compounds were related and they were isomeric. They could not be distinguished by mass spectrometry. The first of the compounds was found with $\mathrm{m} / \mathrm{z} 522.25[\mathrm{M}+\mathrm{H}]^{+}$ and the second having two more protons, a structure of $m / z 524.26[\mathrm{M}+\mathrm{H}]^{+}$, and a loss of 151 Da units. There might be a double bond somewhere in the phorbol part. Six known compounds losing $151 \mathrm{Da}$ were found in the ethanol extract (Table 5). There 
Table 3 Anti-inflammatory activities on NO, TNF- $\alpha$, and IL- 6 of $S$. indica fruit extracts $(n=3)$.

\begin{tabular}{lcccr}
\hline Fruit extract/standard drug & \multicolumn{2}{c}{ Anti-inflammatory $\left(\mathrm{IC}_{50}, \mu \mathrm{g} / \mathrm{ml}\right)$} & $\begin{array}{r}\text { MTT assay } \\
\text { N }\end{array}$ \\
\cline { 2 - 4 } & Nitric oxide & TNF- $\alpha$ & IL-6 Survival \\
\hline Water extract & $>100^{\mathrm{a}}$ & $>100^{\mathrm{a}}$ & $>100^{\mathrm{b}}$ & 82.20 \\
Ethanolic extract & $12.99 \pm 2.42^{\mathrm{b}}$ & $>100^{\mathrm{a}}$ & $>100^{\mathrm{b}}$ & 77.85 \\
Prednisolone & $11.09 \pm 0.27$ & $0.11 \pm 0.001$ & $\mathrm{NT}$ & 82.84 \\
Acetaminophen & $>100$ & $>100$ & $32.14 \pm 2.69$ & 61.29 \\
\hline
\end{tabular}

The extract was considered non-toxic when cell survival $>70 \%$. NT $=$ not tested. Data were analysed by one-way ANOVA and Dunnett's multiple comparison tests. Significant difference (a) is when $p<0.05$ compared with the standard drug (Prednisolone), and (b) is when $p<0.05$ compared with the standard drug (Acetaminophen).

Table 4 Structure elucidation of compounds found in the water extract of $S$. indica fruits using LC-ESI-QTOF-MS/MS operated in positive mode.

\begin{tabular}{|c|c|c|c|c|c|}
\hline$t_{R}(\min )$ & $m / z[\mathrm{M}+\mathrm{H}]^{+}$ & MS/MS* & Tentative identification & Formula & Error (ppm) \\
\hline 24.126 & 540.257 & 389.1951 & Sapintoxin B & $\mathrm{C}_{30} \mathrm{H}_{37} \mathrm{NO}_{8}$ & 4.06 \\
\hline 24.543 & 219.174 & & $\begin{array}{l}\text { (5beta,7beta,10beta)-3,11-Eudesmadien- } \\
\text { 2-one }\end{array}$ & $\mathrm{C}_{15} \mathrm{H}_{22} \mathrm{O}$ & 1.56 \\
\hline 26.922 & 524.2628 & $373.2,313.1789$ & Sapintoxin A & $\mathrm{C}_{30} \mathrm{H}_{37} \mathrm{NO}_{7}$ & 2.82 \\
\hline 27.859 & 524.2624 & 373.1997 & Sapintoxin C & $\mathrm{C}_{30}^{30} \mathrm{H}_{37} \mathrm{NO}_{7}$ & 3.58 \\
\hline 28.191 & 524.2629 & $373.200,355.1891$ & a-Saipinine & $\mathrm{C}_{30} \mathrm{H}_{37} \mathrm{NO}_{7}$ & 2.63 \\
\hline 31.941 & 357.2054 & 300.1916 & $\begin{array}{l}\text { (17Z)-3,11-Dioxopregna-4,17(20)-dien- } \\
\text { 21-oic acid methyl ester }\end{array}$ & $\mathrm{C}_{22} \mathrm{H}_{28} \mathrm{O}_{4}$ & 1.78 \\
\hline 32.504 & 508.2678 & $\begin{array}{l}357.20054, \\
339.1940,315.1946\end{array}$ & $\begin{array}{l}\text { 12-(2-N-methylamino benzoyl)-4a,5,20- } \\
\text { trideoxyphorbol-13-acetate }\end{array}$ & $\mathrm{C}_{30} \mathrm{H}_{37} \mathrm{NO}_{6}$ & 3.08 \\
\hline
\end{tabular}

* means in source fragmentation.

were two compounds with $\mathrm{m} / \mathrm{z} 540.26[\mathrm{M}+\mathrm{H}]^{+}$ at $t_{R}=24.1$ and $26.3 \mathrm{~min}$. The compound at $t_{R}$ 26.3 min was not found in the water extract. We also detected a compound at $\mathrm{m} / \mathrm{z} 522.25$, found only at $t_{R} 29.6 \mathrm{~min}$. Three more compounds were also observed with $\mathrm{m} / z 389.19[\mathrm{M}+\mathrm{H}]^{+}\left(t_{R} 26.6 \mathrm{~min}\right)$, $\mathrm{m} / \mathrm{z} 355.19[\mathrm{M}+\mathrm{H}]^{+}\left(t_{R} 29.3 \mathrm{~min}\right)$, and $\mathrm{m} / z 373.20$ $[\mathrm{M}+\mathrm{H}]^{+}\left(t_{R}\right.$ 30.52). These compounds were likely phorbol skeletons that lost their methylaminobenzoate groups. The negative ionization mode did not reveal any additional information about these six compounds. Other compounds besides these six were previously reported by Chumkaew et al [18].

\section{CONCLUSION}

Thai medicinal herb for treatment of gastritis plays an important role in Thai traditional healthcare services since it can be an effective substitution for Western medicine. Our study gave the first scientific evidence report on bioactivities of the fruit extracts of $S$. indica or Sa-Mor-Ta-Lay. The ethanolic extract of $S$. indica exhibited potent cytotoxic

Table 5 Structure elucidation of compounds found in the ethanolic extract of $S$. indica fruits using LC-ESI-QTOF-MS/MS operated in positive mode.

\begin{tabular}{lcclcc}
\hline$t_{R}(\min )$ & $m / z[\mathrm{M}+\mathrm{H}]^{+}$ & $\mathrm{MS} / \mathrm{MS}^{*}$ & Tentative identification & Formula & Error (ppm) \\
\hline 24.121 & 540.261 & 389.1975 & Sapintoxin B & $\mathrm{C}_{30} \mathrm{H}_{37} \mathrm{NO}_{8}$ & -3.34 \\
26.326 & 540.2607 & 389.1972 & 12 -(2-N-methylamino benzoyl)-4a-deoxy- & $\mathrm{C}_{30} \mathrm{H}_{37} \mathrm{NO}_{8}$ & -2.79 \\
& & & 5,20-dihydroxyphorbol-13-acetate & & \\
26.917 & 524.2667 & 373.202 & Sapintoxin A & $\mathrm{C}_{30} \mathrm{H}_{37} \mathrm{NO}_{7}$ & -4.62 \\
27.774 & 524.2662 & 373.2021 & Sapintoxin C & $\mathrm{C}_{30} \mathrm{H}_{37} \mathrm{NO}_{7}$ & -3.66 \\
28.229 & 524.2663 & 373.2029 & a-Saipinine & $\mathrm{C}_{30} \mathrm{H}_{37} \mathrm{NO}_{7}$ & -3.85 \\
32.531 & 508.2718 & 357.2073 & $\begin{array}{l}\text { 12-(2-N-methylamino benzoyl)-4a,5,20- } \\
\mathrm{C}_{30} \mathrm{H}_{37} \mathrm{NO}_{6}\end{array}$ & -4.79 \\
& & & trideoxyphorbol-13-acetate & & \\
\hline
\end{tabular}

" means in source fragmentation. 
activity against gastric cancer cell lines and antiinflammatory activity on nitric oxide production. Additionally, both the water and the ethanolic extracts showed antioxidant and anti-H. pylori activities. Therefore, $S$. indica has potent activities related to the symptoms of gastritis. However, further investigations into its mechanisms of action on pharmacological activities are still needed for future healthcare benefits.

Acknowledgements: This work was supported by Naresuan University research fund. The authors are grateful to the Faculty of Public Health, Naresuan University and the Faculty of Medicine, Thammasat University for providing logistic support and encouragement to carry out this research. Also, we thank Mr. Paul Freund and Prof. Dr. Duangrudi Suksang for reviewing the manuscript.

\section{REFERENCES}

1. Wirth HP, Yang M (2016) Different pathophysiology of gastritis in East and West? A Western perspective. Inflamm Intest Dis 1, 113-122.

2. Dial EJ, Lichtenberger LM (1986) Development of gastric mucosal protection against acid in the rat. Role of corticosteroids and prostaglandins. Gastroenterology 91, 318-325.

3. Kusters JG, van Vliet AH, Kuipers EJ (2006) Pathogenesis of Helicobacter pylori infection. Clin Microbiol Rev 19, 449-490.

4. Yoshikawa T, Naito Y (2002) What is oxidative stress? Jpn Med Assoc J 45, 271-276.

5. Maneenoon K, Khuniad C, Teanuan Y, Saedan N, Prom-In S, Rukleng N, Wongwiwat W (2015) Ethnomedicinal plants used by traditional healers in Phatthalung Province, Peninsular Thailand. J Ethnobiol Ethnomed 11, ID 43.

6. Dechayont B, Phuakleea P, Chunthorng-Orna, J, Poomirata S, Prajuabjindaa O, Vilaichoneb RK, Itharata A (2019) Anti-Helicobacter pylori, antiinflammatory and antioxidant evaluation of crude extracts from Amomum krervanh fruits. ScienceAsia 45, 109-115.

7. Yamazaki K, Hashimoto A, Kokusenya Y, Miyamoto T, Sato T (1994) Electrochemical method for estimating the antioxidative effect of methanol extracts of crude drugs. Chem Pharm Bull (Tokyo) 42, 1663-1665.

8. Re R, Pellegrini N, Proteggente A, Pannala A, Yang M, Rice-Evans C (1999) Antioxidant activity applying an improved ABTS radical cation decolorization assay. Free Radic Biol Med 26, 1231-1237.
9. Makchuchit S, Rattarom R, Itharat A (2017) The antiallergic and anti-inflammatory effects of Benjakul extract (a Thai traditional medicine), its constituent plants and its some pure constituents using in vitro experiments. Biomed Pharmacother 89, 1018-1026.

10. Jin SE, Kim OS, Yoo SR, Seo CS, Kim Y, Shin HK, Jeong SJ (2016) Anti-inflammatory effect and action mechanisms of traditional herbal formula GamisoyoSan in RAW 264.7 macrophages. BMC Complement Altern Med 16, ID 219.

11. Saraphanchotiwitthaya A, Sripalakit P (2015) Antiinflammatory activity of a Vernonia cinerea methanolic extract in vitro. ScienceAsia 41, 392-399.

12. Atapour M, Zahedi MJ, Mehrabani M, Safavi M, Keyvanfard V, Foroughi A, Siavoshi F, Foroumadi A (2009) In vitro susceptibility of the Gram-negative bacterium Helicobacter pylori to extracts of Iranian medicinal plants. Pharm Biol 47, 77-80.

13. Wong WM, Xiao SD, Hu PJ, Wang WH, Gu Q, Huang JQ, Wong BY (2005) Standard treatment for Helicobacter pylori infection is suboptimal in non-ulcer dyspepsia compared with duodenal ulcer in Chinese. Aliment Pharmacol Ther 21, 73-81.

14. CLSI (2003) Methods for Dilution Antimicrobial Susceptibility Tests for Bacteria that Grow Aerobically, 6th edn, Clinical and Laboratory Standards Institute document M7-A6, PA, USA.

15. Skehan P, Storeng R, Scudiero D, Monks A, McMahon J, Vistica D, Boyd MR (1990) New colorimetric cytotoxicity assay for anticancer-drug screening. $J$ Natl Cancer Inst 82, 1107-1112.

16. Keawpradub N, Eno-Amooquaye E, Burke PJ, Houghton PJ (1999) Cytotoxic activity of indole alkaloids from Alstonia macrophylla. Planta Medica $65,311-315$.

17. Ahmed MI, Hasan MS, Uddin SJ, Rahman AA, Masud MM (2007) Antinociceptive and antioxidant activities of the ethanolic extract of Excoecaria indica. Dhaka Univ J Pharm Sci 6, 51-53.

18. Chumkaew P, Karalai C, Ponglimanont C, Chantrapromma K (2003) Antimycobacterial activity of phorbol esters from the fruits of Sapium indicum. J Nat Prod 66, 540-543.

19. Kai H, Ito M, Kitadai $Y$, Tanaka S, Haruma K, Chayama K (2004) Chronic gastritis with expression of inducible nitric oxide synthase is associated with high expression of interleukin-6 and hypergastrinaemia. Aliment Pharmacol Ther 19, 1309-1314.

20. Lahner E, Carabotti M, Annibale B (2018) Treatment of Helicobacter pylori infection in atrophic gastritis. World J Gastroenterol 24, 2373-2380. 